\title{
E-Perfromance Calculator for Employees in Private Firm
}

\author{
S. Robin, G. Santhoshkumar, R. Velanganni
}

\begin{abstract}
PAS is a basic HRD framework organized and utilized for the general progression and advancement of laborers similarly as affiliations PAS is being used to survey whether agents as various measurements play out their doled out jobs as indicated by the wants for their directors and set benchmarks.

PAS is being used to survey whether laborers at various measurement play out their doled out businesses as per the wants for their chiefs and set standards.

The information delivered from such execution assessment designer generally help the organization to complete certain definitive and developmental decisional concerning assurance, game plan, progression, prizes, getting ready and end.

Father is a key in the hands of people to consider their own one of a kind aptitudes and issues related to their execution. The $P A$ methodology enables manufacturing an imaginative affiliation fit for dealing with its issues and achieving concentrated on business targets.
\end{abstract}

Keywords: HRD framework, PA methodology

\section{INTRODUCTION}

Every affiliation accomplishment depends upon the quality, limit and properties of its laborers. The agents become a basic factor and they are the center of the association. The association can't accomplish their objectives and targets without the productive of representatives .So agents need to incite him with the objective that he is prodded to work at the best energy of the association. It is appeared of the more fundamental approach to manage HRM game plans which looked to interface the purposes of the individual. The affiliations' guideline point is to transformed into an embedded bit of the method in the execution the officials and passed on through the execution assessment process.[1]-[4] Execution examination is the technique embraced by each organization to know the degree of execution of each representative in the association. It helps HR chief for pay builds advancement of the workers. It is to evaluate the capacity of representatives of his assignment. It is a methodical assessment done by the administrators about the presentation of each subordinate. In light of the execution levels of the representatives association needs to inspire them and it is additionally reason for research and reference for work force choices in future. Diverse technique can be utilized to quantify and assess representative's exhibition.

Revised Manuscript Received on December 11, 2019.

S. Robin, Assistant professor, Department Of Science \& Humanities, Bharath Institute of Higher Education and Research ,Chennai, India.Email:srobin@gmail.com

G. Santhoshkumar, Assistant professor, Department Of Science \& Humanities, Bharath Institute of Higher Education and Research ,Chennai, India..Email santhoshravi671026@gmail.com

R. Velanganni, Assistant professor, Department Of Science \& Humanities, Bharath Institute of Higher Education and Research ,Chennai, India. .Email velangannijose78516@gmail.com
These techniques have its own qualities and shortcoming might be appropriate for evaluation.[5]-[8]

\section{OBJECTIVES OF THE STUDY}

1. To think about execution examination

2. To realize the techniques connected in Performance Appraisal

3. To think about the idea of Job.

4.To know the degree of representatives through evaluation.

\section{DESIGN OF THE STUDY}

Scope of Research

1. We can foresee the exhibition examination of comparable sort of associations

2. We can improve the present execution measures.

3. We can redress or fill hole between the desires for the representatives.[21]-25]

\section{RESEARCH Methodology}

Research Design

Research is a simple analytical research based on random sampling method.

\section{RESULTS \& DISCUSSION}

- $35 \%$ of the workers experienced combined examination strategy for execution endorsement.

- $85 \%$ of the workers have mindfulness on execution endorsement.

- $75 \%$ of the representatives concede to execution endorsement.

- $40 \%$ of the workers get execution endorsement once in 2 years.

- $30 \%$ of the representatives firmly concur about the help of top administration

- $48 \%$ of the workers have nonpartisan feeling about the co-appointment of predominant with subordinate.

- $71 \%$ of the workers get different terms of remunerations.

- $33 \%$ of the workers concur that end is the discipline for the back of execution.

- $78 \%$ of the workers are fulfilled on execution endorsement.[9]-[10]

\section{SUGGESTIONS}

- Performance evaluation framework ought to be improved then mindfulness ought to be made on it.

- Top the board bolster was well fundamental for execution examination 
framework. It ought to be marginally improved to show signs of improvement results.

- Punishment on absence of execution ought not resemble end, redress their slip-ups.

- If we pursues the above recommendation. We get high level of occupation fulfillment on our work.[11]-[15]

\section{CONCLUSION}

- Around $1 / 3$ of the representatives are under grievances examination strategy.

- Majority of the representatives have mindfulness on execution endorsement.

- $3 / 4$ of the representatives concede to execution endorsement.

- Nearly $1 / 2$ of the representatives get execution endorsement in 2 years.

- Approval $1 / 3$ of the workers unequivocally concurs about the help of top administration.

- Nearly $1 / 2$ of the workers have impartial sentiment about the co-appointment of predominant with subordinates.

- Nearly $3 / 4$ of the workers get different terms of remunerations.

- $1 / 3$ of the workers concur that end is the discipline for back of execution.

- Nearly $3 / 4$ of the workers are fulfilled on execution endorsement.[16]-[20]

\section{REFERENCES}

1. Vasanthi, S. \& Rabiyathul Basariya, S. 2019, "Influence of value analysis and cross training in industry", International Journal of Engineering and Advanced Technology, vol. 8, no. 6, pp. 1810-1811.

2. Velvizhi, R., Sri Gowtham, S. \& Jeya Priya, D. 2019, "Examination of early feedbacks for effective product retailing on E-commerce websites", International Journal of Engineering and Advanced Technology, vol. 8, no. 6 Special Issue 2, pp. 703-706.

3. Anuradha, C., Pothumani, S. \& Kavitha, R. 2019, "A novel method towards E-commerce", International Journal of Engineering and Advanced Technology, vol. 8, no. 6 Special Issue 2, pp. 535-538.

4. Thomas, J. \& Rabiyathul Basariya, S. 2019, "A study on the issues of financial ratio analysis", Indian Journal of Public Health Research and Development, vol. 10, no. 3, pp. 1079-1081.

5. Ramachandran, S. \& Rabiyathul Basariya, S. 2019, "Online marketing study on customer satisfaction and relationship", Indian Journal of Public Health Research and Development, vol. 10, no. 3, pp. 1072-1078.

6. Priya, R., Vinothini, G. \& Cor Jesu, C.D. 2019, "The mentor-protégé relationship for professional growth", Journal of Advanced Research in Dynamical and Control Systems, vol. 11, no. 9 Special Issue, pp. 1110-1119.

7. Jannifer Rani, N., Bina Pani, S. \& Nimisha, N.S. 2019, "A study on money back polices available in LIC", Journal of Advanced Research in Dynamical and Control Systems, vol. 11, no. 9 Special Issue, pp. 833-839

8. Saillaja, V., Jhansi Rani, K. \& Catherine, R. 2019, "Global marketing management planning and organization", Journal of Advanced Research in Dynamical and Control Systems, vol. 11, no. 9 Special Issue, pp. 489-493.

9. Saillaja, V., Jhansi Rani, K. \& Catherine, R. 2019, "The new phase of marketing information system", Journal of Advanced Research in Dynamical and Control Systems, vol. 11, no. 9 Special Issue, pp. 482-488.

10. Thoufiqulla \& Raju, D.V. 2019, "Perception of indian investor towards investment in mutual funds with special reference to mip funds", Journal of Advanced Research in Dynamical and Control Systems, vol. 11, no. 5, pp. 177-183.

11. Jasmine, K.R.M. \& Basariya, S.R. 2018, "A study on the customers benefits on mutual funds", International Journal of Civil Engineering and Technology, vol. 9, no. 4, pp. 45-48.

12. Vasanthi, S. \& Basariya, S.R. 2019, "Pros and cons of on the job training versus off the job training", International Journal of Scientific and Technology Research, vol. 8, no. 10, pp. 671-674.
13. Pavithra, J. \& Ganesan, M. 2016, "A study on awareness and impact of micro-financial schemes", International Journal of Applied Business and Economic Research, vol. 14, no. 8, pp. 5449-5460.

14. Pavithra, J., Dilli Babu, P. \& Ambuli, T.V. 2014, "A study on budgetary control at Maruti Service Masters, Chennai", International Journal of Applied Business and Economic Research, vol. 12, no. 2, pp. 151-161.

15. Gunaraja, T.M. \& Venkatrama Raju, D. 2018, "Determining factors of organisational climate with reference to leadership styles", International Journal of Mechanical Engineering and Technology, vol. 9, no. 9, pp. 1327-1332.

16. Gunaraja, T.M. \& Venkatrama Raju, D. 2018, "The role of job satisfaction and training of employees in determining organisational climate of a selected industry", International Journal of Civil Engineering and Technology, vol. 9, no. 8, pp. 1266-1269.

17. Aarathy, T.S. \& Raju, D.V. 2018, "Performance appraisal and its effects on employees with respect to it sector in Chennai city", International Journal of Civil Engineering and Technology, vol. 9, no. 6, pp. 1535-1538.

18. Aarathy, T.S. \& Raju, D.V. 2018, "Employee perception towards performance appraisal system in IT sector", International Journal of Mechanical Engineering and Technology, vol. 9, no. 5, pp. 131-135.

19. Porselvi, W., Jublee, D. \& Sivanesan, G. 2018, "A study on factors influencing adoption of technology and innovation in banking industry, tamilnadu, India", International Journal of Mechanical Engineering and Technology, vol. 9, no. 5, pp. 789-800.

20. Akessa, G.M. and Dhufera, A.G., 2015. Factors That Influences Students Academic Performance: A Case of Rift Valley University, Jimma, Ethiopia. Journal of Education and Practice, 6(22), pp.55-63.

21. Miller, G. and Shih, C.C., 1999. A faculty assessment of the academic rigor of on-and off-campus courses in agriculture. Journal of Agricultural Education, 40, pp.57-65.

22. Tsinidou, M., Gerogiannis, V. and Fitsilis, P., 2010. Evaluation of the factors that determine quality in higher education: an empirical study. Quality Assurance in education, 18(3), pp.227-244.

23. Farooq, M.S., Chaudhry, A.H., Shafiq, M. and Berhanu, G., 2011. Factors affecting students' quality of academic performance: a case of secondary school level. Journal of quality and technology management, 7(2), pp.1-14.

24. Fitsilis, P., Gerogiannis, V. and Anthopoulos, L., 2014. Ontologies for software project management: a review. Journal of Software Engineering and Applications, 7(13), p.1096.

25. Adams, J.D. and Jaffe, A.B., 1996. Bounding the effects of R\&D: an investigation using matched establishment-firm data(No. w5544). National bureau of economic research.

\section{AUTHORS PROFILE}

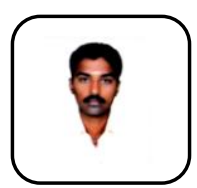

S. Robin, Assistant professor, Department Of Science \& Humanities, Bharath Institute of Higher Education and Research,Chennai, India

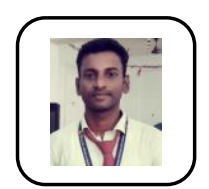

G. Santhoshkumar, Assistant professor, Department Of Science \& Humanities, Bharath Institute of Higher Education and Research ,Chennai, India. .

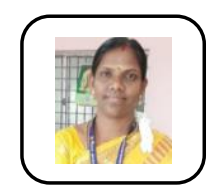

R. Velanganni, Assistant professor, Department Of Science \& Humanities, Bharath Institute of Higher Education and Research,Chennai, India 